\title{
SIAE Gene
}

National Cancer Institute

\section{Source}

National Cancer Institute. SIAE Gene. NCI Thesaurus. Code C91282.

This gene plays a role in sialic acid modification. 